\title{
Studi Perbandingan Pengaturan tentang Pengecualian Industri Pertanian Terhadap Berlakunya Hukum Persaingan Usaha
}

\author{
Siti Anisah \\ Fakultas Hukum Universitas Islam Indonesia \\ Jl. Tamansiswa No. 158 Yogyakarta \\ anisahraharjo@gmail.com
}

\begin{abstract}
The research is aimed at finding out whether the exemption for agricultural industries in the competition laws in Unites States of America and European Union is fully or partially granted. In addition, the study examines whether the competition law in Indonesia also regulates exemption for agricultural industries. The research method is normative juridical with a legal comparison approach. The result shows that the exemption for agricultural industries in the United States of America mentioned in the antitrust law was regulated by the Congress through Clayton Act 1916 and confirmed in Capper-Volstead Act 1922. In European Union, the exemption is regulated in the Treaty Establishing the European Community. The regulations in the United States and European Union are the same, in which farmers are allowed to establish agricultural cooperatives that aim to meet the needs of its members, such as collective processing, preparation for markets, merchants, and marketing. Although Indonesia does not have a specific law for exemption, several stipulations in Article 50 and 51 of Law No. 5 Year 1999 can be interpreted as exemption for agricultural industries in the competition law.
\end{abstract}

Key words : Comparison, competition law, agricultural industry, exclude, cooperatives

\begin{abstract}
Abstrak
Penelitian ini difokuskan untuk mencari pengaturan tentang pengecualian industri pertanian terhadap berlakunya hukum persaingan usaha di Amerika Serikat dan Uni Eropa diberikan secara keseluruhan atau parsial. Apakah hukum persaingan usaha Indonesia mengatur pengecualian industri pertanian. Metode yang digunakan adalah yuridis normatif dan perbandingan hukum. Penelitian ini menyimpulkan bahwa pengecualian industri pertanian di Amerika Serikat dari berlakunya antitrust law diatur oleh Kongres melalui Clayton Act 1916 selanjutnya dipertegas dalam Capper-Volstead Act 1922. Di European Community, pengecualian termasuk dalam the Treaty Establishing the European Community. Pengaturan di Amerika Serikat dan Uni Eropa sama, yaitu petani dapat membentuk koperasi produk pertanian yang tujuannya untuk memenuhi kebutuhan para anggotanya dari mulai "pemrosesan secara kolektif, persiapan untuk pasar, pedagang dan pemasaran."Meskipun Indonesia tidak memiliki undangundang khusus, beberapa ketentuan dalam Pasal 50 dan Pasal 51 Undang-Undang Nomor 5 Tahun 1999 dapat digunakan untuk mengecualikan industri pertanian dari hukum persaingan usaha.
\end{abstract}

Kata kunci : Perbandingan, bukum persaingan usaba, industri pertanian, pengecualian, koperasi. 


\section{Pendahuluan}

Pengecualian industri pertanian dari berlakunya hukum persaingan usaha dapat ditemukan di banyak negara. ${ }^{1}$ Kebanyakan negara maju menganggap industri pertanian sebagai bidang khusus dari ekonomi yang memerlukan intervensi yang intensif dalam bentuk regulasi, misalnya melalui sistem kuota, mekanisme price support, dan proteksi dari impor. ${ }^{2}$ Kebijakan-kebijakan itu terasa sangat kuat di arena perdagangan internasional, dimana pertanian selalu menjadi pertimbangan setidaknya bagi negara-negara maju- sebagai 'kasus khusus' yang tidak dapat dipengaruhi oleh peraturan perdagangan bebas pada umumnya. ${ }^{3}$

Penolakan dari negara-negara itu untuk membuka sektor pertanian mereka menjadi lebih kompetitif secara internasional, terutama ketika berhadapan dengan produksi dari negara-negara berkembang, telah menyebabkan stagnansi yang panjang di Doha Round of Multilateral Trade Negotiation dalam World Trade Organization(WTO). ${ }^{4}$ Bersamaan dengan kebijakan-kebijakan itu, negara-negara maju juga memberikan pengecualian sama sekali atau pengecualian parsial kepada petani mereka dalam hukum persaingan usaha domestik. Ekonomi dan alasanalasan non-ekonomi (misalnya kebutuhan untuk menjaga komunitas yang terpencil), telah diklaim untuk mencegah peraturan di sektor pertanian dari diberlakukannya mekanisme pasar, dan merupakan mandat kepada Pemerintah untuk mengatur sektor ini. Permintaan dari konsumen yang tidak berubah, ketidakpastian panen dan suplai musiman, serta ketidakmampuan untuk menyimpan dan memproduksi dalam jangka waktu yang lama bagi produkproduk pertanian tertentu, menyebabkan intervensi pemerintah dan pengaturan

${ }^{1}$ Misalnya di Amerika Serikat, pengecualian khusus terhadap industri pertanian diatur dalam the Capper-Volstead Act(P.L. 67-146), the Co-operative Marketing Associations Act (7 U.S.C. 291, 292) yang diadopsi oleh the United States Congress pada 18 Februari 1922. Di European Community, pengecualian termasuk dalam the Treaty Establishing the European Community, di Pasal 36 (ex Pasal 42), sejak lahirnya pada 1957. Di United Kingdom (UK), objek pengecualiannya diatur dalam the Restrictive Trade Practices Act of 1956. Di Israel diatur dalam the Restrictive Trade Practices Law 1988.

${ }^{2}$ Suatu negara dapat memproteksi industri dalam negeri, jika impor produknya meningkat. Mark R. Sandstrom \& David N. Goldsweig, Eds. Negotiating and Structuring International Commercial Transactions, Illinois, ABA Publishing, 2003, hlm. 180.

${ }^{3}$ Arie Reich, "The Agricultural Exemption in Antitrust Law: A Comparative Look at the Political Economy of Market Regulation,” 42 Texas International Law Journal 843, Summer 2007, hlm. 844.

${ }^{4}$ Michael J. Trebilcock \& Robert Howse, The Regulation of International Trade (3d ed. 2005), hlm. 321 - 348. Di WTO, sejak masuknya mekanisme penyelesaian sengketa yang baru dan lebih baik di 1995, 20\% dari perkara yang ditangani di tingkat laporan panel adalah mengenai produk pertanian. Kasus-kasus mengenai produk pertanian yang dibawa sampai tingkat banding, mencapai 33\%. Lihat Donald Buckingham, "World Production Update: Why Agricultural Lawyers Need to Know about International Trade Law," 4 Drake Journal of Agricultural Law 5, Spring, 1999 , hlm. $35-36$. 
sistem pasar yang khusus. ${ }^{5}$ Berbagai alasan itu masih menjadi perdebatan, apakah industri pertanian dapat diberlakukan hukum persaingan usaha yang membebaskan para pelakunya bersaing secara sehat dan tanpa halangan ataukah tidak.

\section{Rumusan Masalah}

Pertama, apakah pengaturan tentang pengecualian industri pertanian terhadap berlakunya hukum persaingan usaha di Amerika Serikat dan Uni Eropa diberikan secara keseluruhan atau parsial? Kedua, apakah hukum persaingan usaha Indonesia mengatur pengecualian industri pertanian?

\section{Tujuan Penelitian}

Penelitian ini bertujuan untuk: pertama, mengkaji apakah pengaturan tentang pengecualian industri pertanian terhadap berlakunya hukum persaingan usaha di Amerika Serikat dan Uni Eropa diberikan secara keseluruhan atau parsial. Kedua, menganalisis apakah hukum persaingan usaha Indonesia mengatur pengecualian industri pertanian.

\section{Metode Penelitian}

Metode penelitian yang digunakan adalah yuridis normatif dan perbandingan hukum (comparative law). Metode yuridis normatif yang digunakan dalam penelitian ini adalah untuk menganalisis data yang mengacu kepada norma-norma hukum yang terdapat dalam peraturan perundang-undangan dan putusan pengadilan. ${ }^{6}$ Metode perbandingan hukum digunakan untuk dapat menemukan jawaban atas permasalahan yang tidak secara khusus diatur dalam sistem hukum Indonesia. ${ }^{7}$ Selain itu, perbandingan hukum dilakukan untuk mengkaji bagaimana sistem hukum yang berbeda mengatasi permasalahan hukum tertentu itu. ${ }^{8}$

${ }^{5}$ Lihat antara lain CYE Consult, "Value Chain Analysis of Slected Commodities Institutional Development Across the Agri-Food Sector (IDAF) - 9 ACP MAI 19,' Final Report, Request for services n²008/159774/1; Arie Reich, Op. Cit., hlm. 846.

${ }^{6}$ Ronald Dworkin, Legal Research, Spring, Daedalus, 1973, hlm. 250.

${ }^{7}$ Lihat Konrad Zweigert \&Hein Kotz, Introduction to Comparative Law,3ded, Clarendon Press, Oxford, 1998, hlm. 15.

${ }^{8}$ Pendekatan ini disebut dengan pendekatan fungsi atau konteks (functionorcontext approach). Lihat David J. Gerber, "Globalization and Legal Knowlegde: Implications for Comparative Law," 75 Tullane Law Review 949, Maret 
Penelitian ini menggunakan data sekunder, yang terdiri dari bahan hukum primer, sekunder dan tersier. Bahan hukum primer berupa peraturan perundangundangan. Bahan hukum sekunder berupa peraturan perundang-undangan dan putusan pengadilan di Amerika Serikat dan Uni Eropa. Bahan hukum tersier yaitu bahan hukum yang dapat menjelaskan bahan hukum primer dan sekunder, antara lain berupa kamus.

Analisis data dalam penelitian ini menggunakan pendekatan yang bersifat kualitatif. Analisis data dilakukan secara menyeluruh dan merupakan satu kesatuan (holistic). Metode yang demikian mengingat penelitian ini tidak mementingkan kuantitas datanya, tetapi lebih mementingkan kedalamannya. ${ }^{9}$

\section{Hasil Penelitian dan Pembahasan}

\section{Pengecualian Pertanian di dalam US Antitrust Law}

Pengecualian bidang yang berkaitan dengan pertanian di Hukum Federal Amerika Serikat telah diatur oleh Kongres melalui Clayton Act 1916 dan CapperVolstead Act $1922 .{ }^{10}$ Sebelum dua regulasi itu lahir, di banyak undang-undang di negara bagian telah memiliki peraturan dengan isi dan tujuan yang sama-yaitu untuk memberi otorisasi adanya koperasi pertanian, dan membebaskan mereka dari kewajiban yang diatur dalam antitrust law. ${ }^{11}$ Latar belakang dari pengecualian ini adalah sifat dasar dari industri pertanian yang atomistis dan ketidakmampuan petani individu untuk melakukan tawar menawar dengan beberapa perusahaan yang mendominasi proses dan pemasaran produk pertanian. Para petani itu banyak dan tersebar, serta wilayahnya terisolasi dari satu dengan yang lainnya dan dari konsumen mereka, sehingga membuat para petani itu menjadi "mangsa empuk" bagi perusahaan-perusahaan pemasaran yang mengambil manfaat dari kondisi pertanian itu.

Untuk menandingi kekuatan perusahaan-perusahaan pemasaran dan meningkatkan taraf hidup mereka, petani-petani harus mengorganisasikan diri

\footnotetext{
${ }^{9}$ Lihat C. Marshall \&G. Rossman, Designing Qualitative Research, 3rd edn, Thousand Oak: Sage Publications, 1999.

${ }^{10}$ Capper-Volstead Act \291 (1922).

${ }^{11}$ A. Ladru Jensen, “The Bill of Rights of U.S. Cooperative Agriculture,"20 Rocky Mountain Law Review 181, 1948, hlm. 191.
} 
mereka dalam sebuah koperasi. Organisasi-organisasi inilah yang diharapkan dapat menyediakan transportasi dan jasa pemasaran untuk para petani, sehingga menghubungkan mereka dengan konsumen dengan lebih baik. Ini akan membuat mereka mendapatkan harga yang lebih baik atau tinggi untuk produknya dan membangun sistem produksi dan distribusi yang lebih efektif dan adil. Namun, organisasi semacam itu bermasalah dari sisi antitrust. Koperasi antara para petani dalam rangka menetapkan harga umum untuk produksi dan pemasaran mereka secara bersama-sama nampaknya merupakan pelanggaran terhadap Sherman Act mengenai pelarangan perjanjian untuk mengendalikan perdagangan. ${ }^{12}$ Praktiknya, beberapa koperasi dinyatakan terbukti bersalah atas pelanggaran terhadap antitrust oleh pengadilan. ${ }^{13}$

Clayton Antitrust Act hanya memberikan otorisasi kepada petani untuk mengorganisasikan mereka sendiri ke dalam koperasi (dan kepada buruh ke dalam serikat) "dengan tujuan untuk saling menolong." ${ }^{14}$ Selama mereka "secara legal melaksanakan hal-hal yang diperbolehkan oleh hukum" mereka tidak dapat dikatakan ilegal di bawah antitrustlaw. Namun, "tolong menolong" yang seperti apa yang dapat diberlakukan kepada anggotanya, dan apakah persisnya "hal-hal yang diperbolehkan secara hukum"? Dalam rangka menjelaskan hal itu, dan juga untuk memungkinkan koperasi tersebut untuk meningkatkan modal yang diperlukan untuk operasi mereka secara efisien, kongres mengeluarkan CapperVollstead Act pada 1922. ${ }^{15}$

Capper-Volstead Act 1922 mengidentifikasi hal-hal yang diperbolehkan untuk koperasi produk pertanian berupa "pemprosesan secara kolektif, persiapan untuk pasar, pedagang dan pemasaran" produk pertanian bagi anggotanya untuk keuntungan bersama. ${ }^{16}$ Produsen dari produk-produk tersebut diartikan sebagai “orang yang melakukan produksi atas produk pertanian seperti petani, penanam, peternak, orang yang bekerja di bidang susu dan produknya, penanam kacangkacangan atau buah-buahan."Sementara undang-undang memperbolehkan koperasi

\footnotetext{
12 "Every contract, combination in the form of trust or otherwise, or conspiracy, in restraint of trade or commerce among the several states, or with foreign nations, is declared illegal..." Lihat Sherman Act of 1890, 15 U.S.C $\int 1$.

${ }^{13}$ Misalnya Ford v. Chicago Milk Shippers' Ass'n, 39 N.E. 651 (1895); Reeves v. Decorah Farmers' Coop. Soc'y, 140 N.IW. 844 (1913). Lihat Arie Reich, Op.Cit., hlm. 847.

${ }^{14}$ Clayton Antitrust Act, 15 U.S.C. $\$ \int 6$ (1914).

${ }^{15}$ Capper-Volstead Act, 7 U.S.C. \$S 291-292 (1922).

${ }^{16}$ Capper-Volstead Act, 7 U.S.C. SS 291 (1922).
} 
untuk mengeluarkan saham, dengan tetap membebankan beberapa syarat yang bertujuan untuk menjamin organisasi tersebut akan memelihara sifat dasarnya sebagai koperasi untuk kepentingan anggota-anggotanya: pertama, bahwa tidak ada anggota dari perkumpulan yang mempunyai lebih dari satu suara karena jumlah saham atau modal dasar anggota yang mungkin dimiliki; atau kedua, bahwa perkumpulan tersebut tidak boleh membayar dividen dari saham atau modal anggota lebih dari 8\% per tahun; dalam keadaan apapun. Ketiga, bahwa perkumpulan tersebut tidak boleh melakukan transaksi atas produk non-anggota dengan jumlah yang lebih banyak dari yang dibeli dari anggotanya. Perkumpulan yang memenuhi syaratsyarat tersebut diperbolehkan untuk melakukan kerjasama dalam penentuan harga dan kondisi penjualan. Bahkan bekerjasama dengan perkumpulan lain yang sejenis dalam menentukan agen pemasaran umum—namun jika sebaliknya, akan dianggap ilegal di bawah Sherman Act. ${ }^{17}$

Meskipun begitu, Caper-Vollstead Act juga menambahkan sebuah pengaman yang penting. Undang-undang ini menugaskan the Secretary of Agriculture dengan tanggung jawab untuk melakukan tindakan jika ia yakin bahwa ada perkumpulan yang "memonopoli atau mengontrol perdagangan... sampai menyebabkan harga produk pertanian menjadi sangat tinggi." Di kasus seperti itu, sebuah dekrit dapat dikeluarkan untuk perkumpulan tersebut agar menghentikan perbuatannya. Dengan kata lain, pengecualian bukanlah otorisasi yang mengekang untuk melakukan perilaku anti-kompetisi yang merugikan konsumen. Sementara tujuannya untuk melindungi petani dari kekuatan pihak yang melakukan monopsoni. Hal ini tidak boleh dilakukan dengan mengorbankan konsumen. Kongres tidak mau memberikan imunitas kepada perkumpulan petani-seperti memperbolehkan mereka untuk mengembangkan kekuatan monopoli terhadap konsumen-Seperti yang disebutkan dalam House Report: “Jika perkumpulan yang diberi kewenangan oleh undangundang ini melakukan hal yang dilarang dalam Sherman Antitrust Act, maka mereka dapat diberi hukuman berdasar undang-undang tersebut. Undang-undang tersebut bukan menempatkan perkumpulan tersebut di atas hukum, namun untuk memberikan imunitas yang sama dari tuntutan yang sekarang dinikmati oleh korporasi sehingga mereka dapat menjalankan bisnis mereka dengan sukses dalam berkompetisi dengan korporasi-korporasi tersebut."18

\footnotetext{
${ }^{17}$ Arie Reich, Op. Cit., hlm. 848.

${ }^{18}$ Ibid.
} 
Pengadilan Amerika Serikat juga diberi otorisasi oleh undang-undang, bersama dengan the Secretary of Agriculture, untuk mencegah penyalahgunaan pengecualian ini. Di kasus Maryland E Virginia Milk Producers Association v. Unites States, misalnya, Mahkamah Agung menyebutkan bahwa bagian 2 Capper-Volstead Act bukan bertujuan untuk memberikan jurisdiksi eksklusif terhadap penyalahgunaan ini kepada the Secretary of Agriculture, sehingga tidak memasukkan penuntutan apapun di bawah Sherman Act. Dengan demikian, ketika ada perilaku anti-kompetisi dalam perkumpulan petani yang menyebabkan kenaikan harga yang terlalu tinggi, dapat dituntut dengan menggunakan antitrust law yang berlaku. Dalam kasus ini, petani yang terbukti melakukan percobaan monopoli dan melakukan beberapa perjanjian anti-kompetisi, diperintahkan untuk membatalkan semua kontrak-kontrak tersebut dan untuk melepaskan diri dari semua aset yang dibeli dari saingannya. Mahkamah Agung itu membatasi pengecualian yang diberikan oleh Capper-Volstead Act kepada pembentukan koperasi dan tidak sampai kepada aktifitas non-kompetitif mereka, seperti bergabung dengan pesaing yang bukan merupakan koperasi yang mendapat pengecualian atau menggunakan posisi dominan untuk menekan kompetisi dengan produsen dan pemroses independen. ${ }^{19}$

Pengecualian di bidang pertanian di Amerika Serikat dibuat untuk membetulkan distorsi kompetisi di sektor pertanian dan memungkinkan petani untuk menyaingi kekuatan pasar monopsoni atau oligosoni oleh pihak perantara. Karenanya, pengecualian ini hanya sampai kepada pembentukan koperasi antara petani, dan hanya di antara mereka dan kepada hal-hal yang diperbolehkan secara hukum untuk dilakukan oleh koperasi-koperasi tersebut, termasuk kerjasama dalam bidang pemrosesan, pembelian dari petani dan pemasaran. Sebuah koperasi harus dijalankan atas kepentingan bersama dan membagi keuntungan di antara mereka dengan batas tertinggi pembagian dividen sebesar $8 \%$ per tahun, dan mereka tidak kebal terhadap pengawasan secara administratif maupun hukum.Artinya, jika mereka melakukan tindakan anti-kompetitif, misalnya menggabungkan diri dengan pesaing, penyalahgunaan posisi dominan dan merger, maka mereka dikenakan sanksi sesuai dengan antitrust law. ${ }^{20}$

\footnotetext{
${ }^{19}$ Ibid.

${ }^{20}$ Ibid., hlm. 849.
} 


\section{Pengecualian Industri Pertanian di European Community Treaty}

Pengecualian bidang pertanian di European Community (EC) sama bentuknya dengan yang diterapkan oleh Amerika Serikat. Di European Community, fokus pengaturannya untuk memungkinkan penggunaan perkumpulan petani yang efisien dalam bentuk koperasi produk pertanian. Jika pengecualian ini tidak ada, maka koperasi dapat dikatakan melanggar Pasal 81 European Community Treaty. ${ }^{21}$ Alasan yang melatarbelakangi pengaturan ini adalah sifat dasar dari sektor pertanian yang atomistik. Industri pertanian dibangun dari banyak pertanian kecil yang dijalankan oleh keluarga. Untuk itu, merupakan suatu kebutuhan mendesak untuk mendorong pendirian koperasi dalam rangka meningkatkan efisiensi dan daya saing. Hal yang berbeda dari ketentuan di Amerika Serikat, pengecualian ini bertujuan untuk memungkinkan kebijakan yang tepat oleh pemerintah pusat di sektor pertanian, terutama Common Agricultural Policy (CAP) dari European Community, dan beberapa kebijakan nasional masing-masing negara anggota. Namun, kebijakan bidang pertanian, dan khususnya aturan dalam European CommunityTreaty lebih diutamakan. Aturan tentang pengecualian telah dibuat oleh European Community Council pada 1962 dalam Council Regulation 26 untuk menyatakan otorisasi dari European CommunityTreaty. ${ }^{22}$

Pasal 2 (1) Council Regulation 26 menyatakan bahwa Pasal 81 (1) European Community Treaty tidak dapat digunakan untuk perjanjian-perjanjian, keputusan-keputusan dan praktik-praktik [yang berhubungan dengan produksi atau perdagangan produkproduk yang terdapat dalam daftar di Annex I dalamEuropean CommunityTreaty] yang merupakan bagian integral dari sistem pasar nasional atau hasil dari tujuan yang telah disepakati dalam Pasal 33 European Community Treaty. Secara khusus, ini tidak diberlakukan dalam perjanjian-perjanjian, keputusan-keputusan, dan praktikpraktik dari petani, perkumpulan petani, atau perkumpulan petani yang merupakan milik salah satu negara anggota yang bergerak di bidang produksi atau penjualan produk pertanian atau penggunaan gudang secara bersama-sama, perlakuan atau pemrosesan produk pertanian, dan dimana tidak ada kewajiban untuk

${ }^{21}$ Article 81 of the EC Treaty prohibits "agreements between undertakings [which could include individual farmers], decisions by associations of undertakings and concerted practices which ... have as their object or effect the prevention, restriction or distortion of competition within the common market, and in particular those which: (a) directly or indirectly fix purchase or selling prices or any other trading conditions..."

${ }^{22}$ Gerrit Meester, "European Union, Common Agricultural Policy, and World Trade," 14 Kansas Journal of Law \& Public Policy 389, Winter, 2005, hlm. 391 - 392; Arie Reich, Op. Cit., hlm. 850. 
pertanggungjawaban terhadap harga yang sama, kecuali jika Comissionand the European Court of Justice menemukan bahwa ada hambatan untuk masuk (membatasi persaingan) atau tujuan dari Pasal 33 European Community Treaty telah terancam. ${ }^{23}$

Pengecualian itu berhubungan hanya dengan Pasal 81 European Community Treaty. Dengan demikian, Pasal 82, dalam hal penyalahgunaan posisi dominan, dan peraturan tentang merger, tetap berlaku dalam sektor pertanian seperti dalam sektor lainnya. Bahkan pengecualian dalam perjanjian berdasarkan Pasal 81 telah dibatasi secara signifikan oleh interpretasi terbatas dari Commission and the European Court of Justice (ECJ). Pengecualian itu, seperti telah disebutkan di dalam Council Regulation 26, digunakan hanya untuk produk-produk yang terdaftar di Annex I of Treaty.

Pengecualian tidak terbatas pada perjanjian yang disyaratkan untuk pendirian dan penggunaan perkumpulan yang sesuai dengan ketentuan, namun lebih jauh lagi kepada perjanjian-perjanjian lain di antara petani, juga perjanjian-perjanjian dengan perkumpulan petani, atau antar perkumpulan sejenis. Terkait dengan hal ini ada beberapa kualifikasi. Pertama, perkumpulan ini hanya dapat memasukkan petani-petani dari satu negara anggota. Kedua, peraturan menyatakan dengan jelas pelarangan penentuan harga (secara horizontal). Ketiga, seperti di Amerika Serikat, ada pengaman berupa otorisasi dari Commission and the European Court of Justice untuk menyatakan bahwa pengecualian tidak dapat dilaksanakan jika Commission and the European Court of Justice mendapati adanya persaingan usaha yang dihapuskan dengan adanya perjanjian itu atau jika tujuan dari Pasal 33 European Community Treaty telah terancam. Sama seperti di Amerika Serikat, otorisasi ini juga dapat digunakan oleh pengadilan nasional kapanpun mereka diminta untuk melaksanakan aturan-aturan tentang persaingan usaha dalam European Community Treaty. Mereka juga dapat memutuskan-dari beberapa kasus yang relevan dari Commission andthe European Court of Justice dan putusan-putusan yang lalu, dan kebijakan Commission and the European Court of Justice-bahwa perjanjian yang dipermasalahkan telah menghapuskan persaingan usaha, atau mengancam tujuan Common Agricultural Policy, dan akhirnya menyatakan bahwa perjanjian tersebut tidak berlaku. ${ }^{24}$

${ }^{23}$ Lihat lebih lanjut Council Regulation 26/62, Applying Certain Rules of Competition to Production of and Trade in Agricultural Products, 1959-1962 O.J. Spec. Ed. 129. art 2 (1).

${ }^{24}$ Arie Reich, Op. Cit., hlm. 851. 
Berdasarkan prinsip-prinsip tersebut, Commission and theEuropean Court of Justice, dan pengadilan-pengadilan nasional (national courts) harus menguji berbagai perjanjian yang bersifat menghambat (restriktif) di sektor pertanian agar dapat menentukan mana saja yang masuk pengecualian, dan mana saja yang tidak termasuk pengecualian. Secara khusus, Commission andthe European Court of Justice telah menahan pengecualian dari perjanjian yang melibatkan perorangan yang bukan petani dan perkumpulannya, semisal pemroses produk dan penjual, walaupun dilakukan dengan petani. Tidak termasuk ke dalam pengecualian, jika suatu perjanjian dilakukan oleh 5 pihak, yang melibatkan 4 perkumpulan petani dan 1 perusahaan swasta. Beberapa pedagang produk pertanian dan perkumpulannya telah menentang pengecualian yang berlaku di European Community,dengan mengklaim bahwa kalimat kedua dari Pasal 2 (1) Council Regulation 26 telah mendiskriminasi produsen dengan pedagang, dengan tidak memasukkan pedagang ke dalam skema yang menguntungkan itu. Hal ini tidak dapat diterima secara hukum, berdasarkan peraturan bahwa individu tidak dapat melakukan keberatan atas peraturan tersebut, hanya negara anggota European Community. Dengan demikian, keberatan tersebut tidak berhasil dilakukan, karena ada alasan yang kuat untuk memberikan perlakuan yang berbeda kepada petani dan penjual sebagaimana telah dipaparkan di atas. ${ }^{25}$

Perbedaan itu telah diperkuat oleh peraturan penting lainnya yaitu Council Regulation 2200/96 tentang sistem bersama dalam pasar buah-buahan dan sayuran. ${ }^{26}$ Salah satu tujuan dari peraturan ini adalah untuk memperkuat posisi produsen di pasar dalam menghadapi "konsentrasi permintaan yang lebih besar". Dengan kata lain, ketentuan ini berlaku di sektor perdagangan grosir dan retail yang membeli dari petani. Untuk menghadapi konsentrasi ini dan kekuatan pasarnya, "pengelompokan suplai melalui organisasi [produsen] merupakan kepentingan ekonomi". Council Regulation 2200/96 mendorong dibentuknya organisasi-organisasi dengan memberikan mereka peran sentral dalam pasar, mempercayakan kekuatan khusus kepada mereka untuk ikut campur sampai ke sisi suplai dan permintaan pasar, dan menghubungkan bantuan finansial kepada petani. Organisasi-organisasi ini diperbolehkan untuk mengambil produksi dalam jumlah tertentu dari pasar dalam rangka melindungi harga domestik. Ini dapat

\footnotetext{
${ }^{25}$ Ibid.

${ }^{26}$ Council Regulation 2200/96, on the Common Organization of the Market in Fruit and Vegetables, 1996 O.J.
} (L 297). 
dilakukan dengan pembelian maupun pemusnahan terhadap hasil produksi, atau menghilangkannya dari pasar dengan cara lain, seperti pengeksporan bersubsidi. ${ }^{27}$ Selain itu, negara anggota di saat-saat tertentu dapat memperluas aturan yang dibuat oleh wakil dari organisasi produsen kepada non-anggota organisasi yang terletak di wilayah mereka. ${ }^{28}$

Dengan demikian, aturan dalam produksi, pemasaran, standar kualitas, perlindungan terhadap lingkungan, dan penarikan produksi dapat dikenakan kepada non-anggota dalam rangka mendorong organisasi produsen untuk mengontrol pasar, untuk memastikan standar kualitas yang sama, dan untuk mencegah adanya pemanfaatan oleh non-anggota. Akan tetapi, aturan-aturan ini harus diberitahukan kepada Commission and the European Court of Justice, dan jika Commission and the European Court of Justice menemukan bahwa mereka mengeluarkan asas persaingan usaha dari bagian substansial dalam pasar internal, atau bahwa mereka mengancam perdagangan bebas atau jika mereka melakukan perbuatan yang termasuk di dalam Pasal 81 (1) (misalnya, mereka mempunyai tujuan atau yang berimbas kepada pencegahan, pembatasan atau distorsi atas persaingan usaha dalam pasar bersama), Commission and the European Court of Justice dapat memerintahkan negara anggota untuk mencabut organisasi tersebut. ${ }^{29}$

Council Regulation 2200/96 juga mengakui adanya "inter-branch organizations." Organisasi ini didirikan dari representasi aktifitas ekonomi yang berhubungan dengan produksi, perdagangan, dan pemrosesan buah-buahan dan sayuran. Namun, tugas dari organisasi-organisasi ini adalah untuk meningkatkan produksi dan pemasaran buah-buahan dan sayuran secara umum, dengan melakukan riset dan studi terhadap pasar dan meningkatkan ilmu dan transparansi dari proses produksi dan pasar. Sementara Pasal 20 Council Regulations menyatakan bahwa Pasal 81 (1) European Community Treaty tidak berlaku untuk perjanjian dari organisasi cabang yang diakui yang bertujuan untuk mengimplementasikan tindakan-tindakan tersebut. Pengecualian ini hanya berlaku jika tindakan-tindakan tersebut telah diberitahukan kepada Commission and the European Court of Justice, dan Commission and the European Court of Justicetidak menemukan bahwa mereka tidak bertentangan

${ }^{27}$ Ekspor subsidi dalam perdagangan internsional sebenarnya hanya dapat diterapkan bagi negara-negara terbelakang (least developed countries). Lihat Andreas F. Lowenfeld, International Economic Law, Oxford University Press, New York, 2002, hlm. 239.

${ }^{28}$ Arie Reich, Op. Cit., hlm. 852.

${ }^{29}$ Ibid., hlm. 853. 
dengan peraturan dalam European Community. Council Regulations memerintahkan Commission and the European Court of Justice untuk menyatakan perjanjian, keputusan, dan praktik umum dari organisasi itu, berkebalikan dengan peraturan European Community, kapanpun mereka mengarah kepada pembagian pasar dalam European Community, atau mempengaruhi operasi sistem pasar, atau membuat distorsi yang tidak diperlukan dalam persaingan usaha dalam meraih tujuan Common Agricultural Policy oleh organisasi. Perjanjian yang memasukkan penetapan harga, harus dinyatakan telah bertentangan. Ketetapan-ketetapan ini dimaksudkan untuk menjamin bahwa organisasi cabang internal-misalnya, badan-badan yang memasukkan aktor selain petani-tidak digunakan yang mungkin akan merusak persaingan usaha, dan bahwa dalam hal ini mereka akan berada di bawah pengawasan yang terus menerus. ${ }^{30}$

Sementara European Community mempunyai sektor pertanian yang diatur dan banyak diberi subsidi, European Communityjuga melakukan upaya untuk memastikan bahwa persaingan usaha di sektor ini masih dipertahankan. European Community telah memutuskan bahwa kebijakan bidang pertanian, dengan sangat menekankan perlindungan terhadap pendapatan para petani dan memastikan suplai makanan yang teratur, akan memberikan preseden dalam peraturan persaingan usaha, namun hanya sejauh yang diperlukan untuk meraih tujuan dalam Common Agricultural Policy dan melindungi petani. Pembedaan yang jelas dibuat dalam hal ini antara petani dan penjual, sehingga hanya petani yang dibebaskan dari beberapa aturan persaingan usaha, namun tetap berada di bawah pengawasan ketat dari Commission dan pengadilan nasional untuk mencegah distorsi yang tidak proposional dari persaingan usaha. Tujuan dari Council Regulation 26 and 2200/96 adalah untuk meningkatkan efisiensi dari sektor pertanian yang atomistik dan untuk memperkuat petani dalam hubungannya dengan penjual dan pemroses yang membeli dari petanipetani tersebut. Aturan dalam persaingan usaha hanya berkompromi sejauh diperlukan untuk tujuan tersebut dan untuk meraih tujuan-tujuan lain dariCommon Agricultural Policy. ${ }^{31}$

\section{Pengecualian Industri Pertanian dalam Hukum Persaingan Usaha di Indonesia}

Indonesia belum memiliki peraturan perundang-undangan yang secara khusus mengatur tentang pengecualian industri pertanian dari berlakunya hukum

\footnotetext{
${ }^{30}$ Ibid.

${ }^{31}$ Ibid., hlm. 854.
} 
persaingan usaha. Namun demikian, merujuk kepada Undang-Undang Nomor 5 Tahun 1999 tentang Larangan Praktek Monopoli dan Persaingan Usaha Tidak Sehat, ${ }^{32}$ ada beberapa pasal yang dapat digunakan untuk mengecualikan bidang pertanian. Misalnya, beberapa poin pengaturan dalam Pasal 50 Undang-Undang Nomor 5 Tahun 1999, yaitu: "a. perbuatan dan atau perjanjian yang bertujuan melaksanakan peraturan perundang-undangan yang berlaku; atau e. perjanjian kerjasama penelitian untuk peningkatan atau perbaikan standar hidup masyarakat luas; atau f. perjanjian internasional yang telah diratifikasi oleh Pemerintah Republik Indonesia; atau h. pelaku usaha yang tergolong dalam usaha kecil; atau i. kegiatan usaha koperasi yang secara khusus bertujuan untuk melayani anggotanya."

Selajutnya Pasal 51 Undang-Undang Nomor 5 Tahun 1999, menyatakan “Monopoli dan atau pemusatan kegiatan yang berkaitan dengan produksi dan atau pemasaran barang dan atau jasa yang menguasai hajat hidup orang banyak serta cabang-cabang produksi yang penting bagi negara diatur dengan undang-undang dan diselenggarakan oleh Badan Usaha Milik Negara dan atau badan atau lembaga yang dibentuk atau ditunjuk oleh Pemerintah."

Berdasarkan pasal-pasal di atas, selanjutnya akan dikaitkan dengan beberapa pasal dalam Undang-Undang Nomor 18 Tahun 2012 tentang Pangan. ${ }^{33}$ Dalam undang-undang ini sebenarnya terdapat beberapa ketentuan yang dapat digunakan oleh Pemerintah dan Pemerintah Daerah untuk mengecualikan industri pertanian dari hukum persaingan usaha, misalnya dengan pembuatan kebijakan yang bertujuan untuk memenuhi kebutuhan pangan. ${ }^{34}$ Namun demikian, beberapa pasal dalam Undang-Undang Nomor 18 Tahun 2012, ternyata penormaannya justru menjadikan industri pertanian (petani kecil) tetap diberlakukan hukum persaingan usaha, karena Undang-Undang Nomor 18 Tahun 2012 tidak secara tegas memisahkan pelaku usaha kecil dan besar.

Pasal 17 Undang-Undang Nomor 18 Tahun 2012 menyatakan "Pemerintah dan Pemerintah Daerah berkewajiban melindungi dan memberdayakan petani, nelayan, pembudi daya ikan, dan pelaku usaha pangan sebagai produsen pangan." Melalui ketentuan ini, pelaku usaha pangan dikategorikan produsen pangan bersama

\footnotetext{
${ }^{32}$ Selanjutnya ditulis Undang-Undang Nomor 5 Tahun 1999.

${ }^{33}$ Selanjutnya disebut Undang-Undang Nomor 18 Tahun 2012.

${ }^{34}$ Pangan merupakan kebutuhan dasar manusia paling utama. Pemenuhannya diwajibkan kepada Negara, karena bagian dari hak asasi manusia yang dijamin oleh UUD 1945. Negara berkewajiban membangun kedaulatan pangan dan secara mandiri menentukan kebijakan pangan untuk menjamin hak atas pangan bagi rakyat.
} 
dengan petani, nelayan, dan pembudi daya ikan, pemerintah berkewajiban melindungi serta memberdayakannya. Dapat dikatakan, bahwa Pemerintah dan Pemerintah Daerah sebenarnya diberikan "ruang" untuk memberikan perlakuan yang berbeda kepada petani kecil dengan pelaku usaha besar, mengingat bahwa Pemerintah dan Pemerintah Daerah mempunyai kewajiban untuk memenuhi kebutuhan Pangan sebagaimana diatur dalam Pasal 18 Undang-Undang Nomor 18 Tahun 2012. Kewajiban itu adalah mengatur, mengembangkan, dan mengalokasikan lahan pertanian dan sumber daya air; memberikan penyuluhan dan pendampingan; menghilangkan berbagai kebijakan yang berdampak pada penurunan daya saing;melakukan pengalokasian anggaran. Melalui Pasal 18 ini, pemerintah berkewajiban menghilangkan berbagai kebijakan yang berdampak penurunan daya saing. Namun demikian, berdasarkan Pasal 17 di atas, undang-undang tidak membedakan antara pelaku usaha pangan besar dengan produsen pangan lainnya. Pasal 1 angka 39 Undang-Undang Nomor 18 Tahun 2012, menentukan Pelaku Usaha Pangan adalah setiap orang yang bergerak pada satu atau lebih subsistem agribisnis Pangan, yaitu penyedia masukan produksi, proses produksi, pengolahan, pemasaran, perdagangan, dan penunjang. Seharusnya pelaku usaha itu dibedakan atau diberikan kriteria dan kualifikasi yang jelas, sehingga menjadi jelas pula bagi pemerintah, siapa yang harus dilindungi dan diberdayakan, serta siapa yang harus dibatasi. Di Amerika Serikat dan European Community para petani diberikan ruang gerak dalam mengorganisasikan kegiatan usaha mereka sebagaimana diatur dalam Pasal 1 angka 39 di atas, dalam bentuk pendirian koperasi untuk kepentingan anggotanya. Koperasi seperti ini, termasuk sebagai pelaku usaha yang dikecualikan dari berlakunya hukum persaingan usaha di Indonesia, sebagaimana dimaksudkan dalam Pasal 50 huruf i Undang-Undang Nomor 5 Tahun 1999. ${ }^{35}$

Kewajiban Pemerintah dan Pemerintah Daerah untuk memenuhi kebutuhan Pangan dalam Pasal 17 Undang-Undang Nomor 18 Tahun 2012, sesuai dengan makna kedaulatan, kemandirian, dan ketahanan pangan sebagai asas Undang-Undang Nomor 18 Tahun 2012. ${ }^{36}$ Kedaulatan Pangan adalah hak negara dan bangsa yang

${ }^{35}$ Lihat Andi Fahmi Lubis, et.al, Hukum Persaingan Usaha antara Teks dan Konteks, Deutsche Gesellschaft für Technische Zusammenarbeit (GTZ) GmbH, Jakarta ,2009, hlm. 288 - 292.

${ }^{36}$ Undang-Undang Nomor 18 Tahun 2012 menentukan berasaskan kedaulatan dan ketahanan. Padahal, konsep kedaulatan pangan merupakan kritik terhadap konsep ketahanan pangan. Konsep kedaulatan pangan berbasis kepada kemandirian bangsa untuk menetapkan sistem pangan sesuai dengan potensi sumber daya lokal, sementara itu ketahanan pangan berbasis kepada mekanisme pasar. Lihat antara lain Hadiedi Prasaja, "Dari Ketahanan Pangan menuju Kedaulatan Pangan, Refleksi Hari Pangan Sedunia," dalam http://www.spi.or.id/?p=4304, 19 Oktober 2011. Ada juga yang 
secara mandiri menentukan kebijakan pangan yang menjamin hak atas pangan bagi rakyat dan yang memberikan hak bagi masyarakat untuk menentukan sistem pangan yang sesuai dengan potensi sumber daya lokal. ${ }^{37}$ Sementara itu, Kemandirian Pangan adalah kemampuan negara dan bangsa dalam memproduksi pangan yang beraneka ragam dari dalam negeri yang dapat menjamin pemenuhan kebutuhan pangan yang cukup sampai di tingkat perseorangan dengan memanfaatkan potensi sumber daya alam, manusia, sosial, ekonomi, dan kearifan lokal secara bermartabat. ${ }^{38}$ Selanjutnya Ketahanan pangan adalah kondisi terpenuhinya pangan bagi negara sampai dengan perseorangan, yang tercermin dari tersedianya pangan yang cukup, baik jumlah maupun mutunya, aman, beragam, bergizi, merata, dan terjangkau serta tidak bertentangan dengan agama, keyakinan, dan budaya masyarakat, untuk dapat hidup sehat, aktif, dan produktif secara berkelanjutan. ${ }^{39}$

Apabila dalam memenuhi kebutuhan pangan nasional Pemerintah atau Pemerintah Daerah tidak melindungi industri pertanian domestik, atau membebaskannya dari monopoli misalnya, maka akan sulit sekali bagi industri ini untuk bersaing dengan industri sejenis dari luar negeri. ${ }^{40}$ Mengingat bahwa adanya tren meningkatnya ekspor produk-produk pertanian negara-negara maju di dunia. ${ }^{41}$ Sementara itu untuk kebutuhan nasional, Indonesia hingga saat ini masih bergantung kepada impor pangan. Pada semester pertama 2011, impor pangan mencapai US\$ 6.350.000.0000, naik 18,7\% dari periode yang sama tahun 2010 (US\$ 5.350.000.0000). Impor itu meliputi beras, kedelai, jagung, biji gandum, tepung terigu, gula pasir, gula tebu, daging, mentega, minyak goreng, susu, telur unggas, kelapa, kelapa sawit, lada, kopi, cengkeh, kakao, cabai kering, tembakau, bawang merah, dan kentang. Pada

berpendapat bahwa kedaulatan pangan merupakan prasyarat dari sebuah ketahanan pangan. Ketahanan pangan baru akan tercipta kalau kedaulatan pangan dimiliki oleh rakyat. Lihat antara lain http://www.walhi.or.id/id/ruang-media/ siaran-pers/2552-wujudkan-kedaulatan-pangan-tolak-dominasi-korporasi-dalam-penguasaan-pangan-di-jawabarat.html, "Wujudkan Kedaulatan Pangan, Tolak Dominasi Korporasi dalam Penguasaan Pangan di Jawa Barat, 21 Mei 2012; http:/ /www.spi.or.id/?page_id=282, “Konsepsi SPI tentang Kedaulatan Pangan,” 10 Desember 2012.

${ }^{37}$ Pasal 1 angka 2 Undang-Undang Nomor 18 Tahun 2012.

${ }^{38}$ Pasal 1 angka 3 Undang-Undang Nomor 18 Tahun 2012.

${ }^{39}$ Pasal 1 angka 4 Undang-Undang Nomor 18 Tahun 2012.

${ }^{40}$ Lihat Ahmad Rmahdan Siregar, Globalisasi dan Persaingan Usaba, Humaniora, Bandung, 2011, hlm. 24.

${ }^{41}$ Misalnya, pada 1997an, ekspor produksi pertanian (wheat, corse-grains, oilseeds, cattle, pigs, chickens, milk and milk. products, rice, fruits and vegetables, sugar) dari tiga negara anggota NAFTA telah meningkat secara dramatis dalam lima tahun terakhir. Ekspor produk pertanian mencapai 88\% untuk Kanada, 47\% untuk Meksiko, dan 42\% untuk Amerika Serikat, dengan tujuan ekspor utama ke Meksiko yang mengalami peningkatan impor sebesar 75\%, dan Amerika Serikat yang impornya mencapai $72 \%$, sedangkan Kanada mengalami peningkatan impor di bidang produk pertanian hanya sebesar 24\%. Dapat dikatakan bahwa setidaknya kondisi itu diraih berkat pasar yang lebih bebas melalui NAFTA. Lihat Donald Buckingham, Op. Cit., hlm 32. 
2012 impor dilakukan diantaranya pada komoditas beras dan jagung masing-masing dua juta ton, kedelai 1.900.0000 ton, gula 3.060.0000 ton senilai AS $\$ 1.960 .000$ dolar AS. ${ }^{42}$

Salah satu bentuk dari disinsentif ekonomi dalam komoditas pangan adalah persaingan yang tidak adil. Namun sangat disayangkan, tidak ada pengertian lebih lanjut terhadap anak kalimat "persaingan yang tidak adil" terhadap komoditas Pangan.Apakah persaingan yang tidak adil itu terjadi antara pelaku usaha besar ketika berhadapan denga pelaku usaha kecildi dalam negeri; ataukah pelaku usaha domestik berhadapan dengan asing? Selengkapnya Pasal 22 Undang-Undang Nomor 8 Tahun 2012 menentukan bahwa ancaman produksi pangan merupakan kejadian yang dapat menimbulkan kegagalan Produksi Pangan yang disebabkan oleh perubahan iklim; serangan organisme pengganggu tumbuhan serta wabah penyakit hewan dan ikan; bencana alam; bencana sosial; pencemaran lingkungan; degradasi sumber daya lahan dan air; kompetisi pemanfaatan sumber daya Produksi Pangan; alih fungsi penggunaan lahan; dan disinsentif ekonomi. ${ }^{43}$ Disinsentif ekonomi" adalah kondisi ekonomi yang tidak mendukung peningkatan Produksi Pangan nasional, misalnya, ketidakstabilan harga Pangan, persaingan yang tidak adil terhadap komoditas Pangan, dan atau kebijakan yang berdampak negatif pada upaya peningkatan Produksi Pangan dalam negeri, misalnya, pembebasan tarif Impor Pangan atau pengenaan pungutan yang berlebihan. ${ }^{44}$ Dalam kondisi itu, Pemerintah dan Pemerintah Daerah berkewajiban mengantisipasi dan menanggulangi ancaman Produksi Pangan melalui bantuan teknologi dan regulasi. ${ }^{45}$

Selanjutnya Pasal 115 Undang-Undang Nomor 8 Tahun 2012 mengatur Sistem informasi Pangan yang diselenggarakan oleh pusat data dan informasi Pangan. Pusat data dan informasi Pangan wajib melakukan pemutakhiran data dan informasi. Pusat data dan informasi Pangan menyediakan data dan informasi paling sedikit mengenai jenis produk Pangan; neraca Pangan; letak, luas wilayah, dan kawasan Produksi Pangan; permintaan pasar; peluang dan tantangan pasar; produksi; harga; konsumsi; status Gizi; ekspor dan impor; perkiraan pasokan; perkiraan musim tanam dan

\footnotetext{
${ }^{42}$ Lihat antara lain Khudori, "Banjir Pangan Impor," dalam http://www.tempo.co/read/kolom/2011/12/ 06/489/Banjir-Pangan-Impor-, 6 Desember 2011, dan http://www.hukumonline.com/berita/baca/lt507bbb2f173f4/ kebijakan-pemerintah-tak-mengarah-kedaulatan-pangan, "Kebijakan Pemerintah tak Mengarah Kedaulatan Pangan," 15 Oktober 2012.

${ }^{43}$ Intervensi pemerintah seharusnya dilakukan untuk memodifikasi kekuatan pasar yang menindas. Johnny Ibrahim, Hukum Persaingan Usaha Filosofi, Teori, dan Implikasi Penerapannya di Indonesia,Bayu Media, 2007, hlm. 14.

${ }^{44}$ Penjelasan Pasal 22 ayat (1) huruf i Undang-Undang Nomor 8 Tahun 2012.

${ }^{45}$ Knud Hansen,et.al.,Undang-Undang Larangan Praktek Monopoli dan Persaingan Usaha Tidak Sehat, Katalis, Jakarta, 2002, hlm. $1-2$.
} 
musim panen; prakiraan iklim; teknologi pangan; dan kebutuhan pangan setiap daerah. Data dan informasi tersebut dapat diakses dengan mudah dan cepat oleh masyarakat, kecuali yang menyangkut kepentingan negara sesuai dengan ketentuan peraturan perundang-undangan. Data dan informasi yang "menyangkut kepentingan negara" adalah informasi yang dapat membahayakan negara yang berkaitan dengan Cadangan Pangan Nasional, perlindungan usaha dari persaingan usaha tidak sehat, danatau yang diminta belum dikuasai atau didokumentasikan. ${ }^{46}$

Selain dua undang-undang di atas, barangkali ketentuan tentang bidang pertanian dalam World Trade Orgaization (WTO) -melalui green box - dapat digunakan oleh Pemerintah untuk melindungi industri pertanian dalam negeri dengan mengecualikannya dari hukum persaingan usaha, sebagaimana diatur dalam Pasal 50 huruf $\mathrm{f}$ Undang-Undang Nomor 5 Tahun 1999. Green Box adalah bantuan dalam negeri yang tanpa atau minimal efek yang sifatnya mendistorsi perdagangan. Green box melingkupi banyak program pemerintah termasuk layanan umum dari pemerintah, program public stockholding untuk tujuan ketahanan pangan dan bantuan pangan domestik- selama kriteria umum dan beberapa kriteria spesifik lainnya terpenuhi oleh tindakan-tindakan tersebut. Green Boxmemberikan kelanjutan (dan perbaikan) atas program seperti riset, termasuk riset umum, riset yang berkaitan dengan lingkungan, riset yang berhubungan dengan produk tertentu; program pengendalian hama dan penyakit, termasuk tindakan pengendalian hama dan penyakit tanaman secara umum dan yang spesifik; layanan pelatihan tentang pertanian; inspeksi, termasuk layanan inspeksi umum dan inspeksi terhadap produk tertentu untuk kesehatan, keamanan, tujuan penggolongan atau standarisasi; layanan pemasaran dan promosi; layanan infrastruktur, termasuk retikulasi listrik, jalan, dan transportasi lain, pasar, dan fasilitas pelabuhan, fasilitas suplai air, dan lainnya; pengeluaran sehubungan dengan pengumpulan dan holding dari saham publik untuk tujuan ketahanan pangan; dan pengeluaran sehubungan dengan ketentuan tentang bantuan pangan domestik terhadap populasi yang membutuhkan. ${ }^{47}$

Green Box juga menyediakan direct payment kepada petani yang tidak berhubungan dengan keputusan produksi. ${ }^{48}$ Dengan kata lain, meskipun petani

\footnotetext{
${ }^{46}$ Penjelasan Pasal 115 ayat (4) huruf i Undang-Undang Nomor 8 Tahun 2012.

${ }^{47}$ http://www.wto.org/english/tratop_e/agric_e/ag_intro03_domestic_e.htm, Akses 10 Desember 2012.

${ }^{48}$ Direct payment di bawah program pembatasan produksi (Blue Box) dibebaskan dari komitmen jika pembayaran tersebut dibuat di area dan hasil yang ditentukan atau jumlah yang ditentukan. Pembayaran tersebut juga termasuk dalam kategori ini jika dibuat dalam 85\% produksi atau kurang di periode dasar yang telah ditentukan. Sementara Green Box meliputi decoupled payment, di Blue Box, produksi masih dipersyaratkan untuk mendapatkan pembayaran, namun
} 
menerima pembayaran dari pemerintah, pembayaran ini tidak mempengaruhi tipe ataupun volume produksi produk pertanian ("decoupling"). Kondisi ini tidak termasuk hubungan apapun antara jumlah pembayaran di satu sisi, dan produksi, harga atau faktor produksi di tahun- tahun setelah periode dasar ditentukan. Sebagai tambahan, tidak ada produksi yang harus disyaratkan untuk menerima pembayaran tersebut. Kriteria tambahan yang harus dipenuhi tergantung tipe tindakan yang dimaksud, yang mungkin termasuk: decoupled income support measures, asuransi pendapatan dan safety-net, pertolongan terhadap bencana alam, program penyesuaian struktural; dan pembayaran tertentu di bawah program lingkungan dan program bantuan regional. ${ }^{49}$

\section{Penutup}

Pengecualian industri pertanian di Amerika Serikat telah diatur oleh Kongres melalui Clayton Act 1916 selanjutnya dipertegas dalam Capper-Volstead Act 1922. Sebelum dua regulasi itu lahir, di banyak undang-undang di negara bagian telah mempunyai aturan dengan isi dan tujuan yang sama, yaitu untuk memberi otorisasi adanya koperasi pertanian, dan membebaskan mereka dari kewajiban yang diatur dalam antitrust law. Imunitas petani maupun perkumpulan petani dari antitrust law tidak berlaku, jika syarat yang bertujuan untuk menjamin organisasi petani itu akan memelihara sifat dasarnya sebagai perkumpulan untuk kepentingan anggotaanggotanya tidak dipenuhi.Di European Community, pengecualian termasuk dalam the Treaty Establishing the European Community.Jika pengecualian ini tidak ada, maka koperasi dapat dikatakan melanggar Pasal 81 European Community Treaty. Bentukbentuk pengecualiannya sama dengan yang diterapkan oleh Amerika Serikat. Hal yang berbeda adalah, pengecualian bertujuan untuk memungkinkan kebijakan yang tepat oleh pemerintah pusat di sektor pertanian, terutama Common Agricultural Policy (CAP) dari European Community, dan beberapa kebijakan nasional negara anggota. Meskipun Indonesia tidak memiliki undang-undang khusus,beberapa poin dalam Pasal 50 dan Pasal 51 Undang-Undang Nomor 5 Tahun 1999 dapat digunakan untuk mengecuaikan industri pertanian dari hukum persaingan usaha. Selain itu terdapat ketentuan World Trade Organization yang memberikan ruang bagi Indonesia untuk memproteki industri pertanian. Sayangnya, undang-undang teknis terkait dengan 
industri pertanian, justru tidak memberikan ruang bagi industri ini dari pengecualian berlakunya hukum persaingan usaha.

\section{Daftar Pustaka}

Fahmi Lubis, Andi, et. al, Hukum Persaingan Usaha antara Teks dan Konteks, Deutsche Buckingham, Donald, "World Production Update: Why Agricultural Lawyers Need to Know about International Trade Law,"4 Drake Journal of Agricultural Law 5, Spring, 1999.

F. Lowenfeld, Andreas, International Economic Law, Oxford University Press, New York, 2002.

Gerrit Meester, "European Union, Common Agricultural Policy, and World Trade," 14 Kansas Journal of Law \& Public Policy 389, Winter.

Gesellschaft für Technische Zusammenarbeit (GTZ) GmbH, Jakarta, 2009.

Hadiedi Prasaja, “Dari Ketahanan Pangan menuju Kedaulatan Pangan, Refleksi Hari Pangan Sedunia," dalam http://www.spi.or.id/?p=4304, 19 Oktober 2011.

Hansen, Knud, et. al., Undang-Undang Larangan Praktek Monopoli dan Persaingan Usaha Tidak Sehat, Katalis, Jakarta 2002.

Ibrahim, Johnny, Hukum Persaingan Usaha Filosofi, Teori, dan Implikasi Penerapannya di Indonesia, Malang: Bayu Media, 2007.

J. Gerber, David, “Globalization and Legal Knowlegde: Implications for Comparative Law," 75 Tullane Law Review 949, Maret 2001.

J. Trebilcock, Michael \& Robert Howse, The Regulation of International Trade, 3d ed. 2005.

Khudori, "Banjir Pangan Impor," dalam http://www.tempo.co/read/kolom/2011/ 12/06/489/Banjir-Pangan-Impor-, 6 Desember 2011.

Ladru Jensen, A., "The Bill of Rights of U.S. Cooperative Agriculture," 20 Rocky Mountain Law Review 181, 1948.

Marshall, C., \&G. Rossman, Designing Qualitative Research, 3rd edn, Thousand Oak, Sage Publications, 1999.

Rmahdan Siregar, Ahmad, Globalisasi dan Persaingan Usaha, Humaniora, Bandung, 2011.

R. Sandstrom, Mark \& David N. Goldsweig, Eds. Negotiating and Structuring International Commercial Transactions, ABA Publishing, Illinois, 2003.

Reich, Arie, "The Agricultural Exemption in Antitrust Law: A Comparative Look at the Political Economy of Market Regulation," 42 Texas International Law Journal 843, Summer 2007.

Ronald Dworkin, Legal Research, Spring, Daedalus, 1973. 
Ford v. Chicago Milk Shippers' Ass'n, 39 N.E. 651, 1895.

Zweigert, Konrad \& Hein Kotz, Introduction to Comparative Law,3d ed., Clarendon Press, Oxford 1998.

Council Regulation 26/62, Applying Certain Rules of Competition to Production of and Trade in Agricultural Products, 1959-1962.

CYE Consult, "Value Chain Analysis of Slected Commodities Institutional Development Across the Agri-Food Sector (IDAF) - 9 ACP MAI 19," Final Report, Request for services n`2008/159774/1.

Reeves v. Decorah Farmers' Coop. Soc'y, 140 N.W. 844, 1913.

the Capper-Volstead Act (P.L. 67-146).

the Clayton Antitrust Act of 1914 (Pub. L. 63-212, 38 Stat. 730).

the Sherman Act of 1890 (ch. 647, 26 Stat. 209).

the Treaty Establishing the European Community.

Undang-Undang Nomor 18 Tahun 2012 tentang Pangan.

Undang-Undang Nomor 5 Tahun 1999 tentang Larangan Praktek Monopoli dan Persaingan Usaha Tidak Sehat.

http:/ / www.hukumonline.com/berita/baca / lt507bbb2f173f4/kebijakanpemerintah-tak-mengarah-kedaulatan-pangan, "Kebijakan Pemerintah tak Mengarah Kedaulatan Pangan," 15 Oktober 2012.

http:/ / www.spi.or.id/?page id=282, “Konsepsi SPI tentang Kedaulatan Pangan," 10 Desember 2012.

http:/ / www.walhi.or.id/id/ruang-media/siaran-pers/2552-wujudkan-kedaulatanpangan-tolak-dominasi-korporasi-dalam-penguasaan-pangan-di-jawabarat.html, "Wujudkan Kedaulatan Pangan, Tolak Dominasi Korporasi dalam Penguasaan Pangan di Jawa Barat, 21 Mei 2012.

http://www.wto.org/english/tratop e/agric e/ag intro03 domestic e.htm, Akses 10 Desember 2012. 